\title{
The testing of ambivalent sexism theory
}

\section{Çelişik duygulu cinsiyetçilik kuramının test edilmesi}

\author{
Sezer Yudulmaz Ayan* Veda Bilican Gökkaya**
}

*Sosyoloji Bölümü, Cumhuriyet Üniversitesi Edebiyat Fakültesi Sivas
**: Sosyal Hizmet Bölümü, Cumhuriyet Üniversitesi Edebiyat Fakültesi Sivas
Corresponding author: Sezer Yudulmaz Ayan, Sosyoloji Bölümü, Cumhuriyet Üniversitesi Edebiyat Fakültesi Sivas,
Turkey
E-mail: sezerayan@gmail.com
Received/Accepted: January 21,2016/May 05, 2016

Conflict of interest: There is not a conflict of interest.

\section{SUMMARY}

Objective: The aim of this study is to test ambivalent sexism inventory (ASI) and ambivalence towards men inventory (AMI), which were developed on the basis of the Ambivalent Sexism approach.

Method: The sampling was formed by 422 students ( 252 women and 169 men) from University of Cumhuriyet. The data of the study were obtained from the questionnaire determining their sociodemographic characteristics of the students and AMI and ASI in order to determine their tendencies of sexism. After obtaining the permission from the Rectorate of Cumhuriyet University, the application was carried out with the help of academic staff at relevant faculties and vocational schools between 01.02.2012 and 30.04.2012.

Results: When the overall average of the scores obtained from ASI and AMI were considered, it was found out that the ambivalence of the participants against each other (with ASI $x=4,12$; AMI $x=4,22$ ) was above the average; and men (with $x=4,23$ ) had more ambivalence compared to women $(x=4,05)$ in ASI, and women $(x=4,38)$ had more ambivalence compared to men $(\mathrm{x}=3,99)$ in AMI. The data obtained from the variance analysis suggested that there were significant differences among the participants by gender, which were Hostile sexism (HS) for men $(\mathrm{t}(421)=-7,99 \mathrm{p}<0,05)$, Benevolent sexism (BS) for women $(\mathrm{t}(421)=4,28 \mathrm{p}<0,05)$ in ASI; and Hostility attitudes towards men (HM) for women $(\mathrm{t}(421)=-15,33 \mathrm{p}<0,05)$, Benevolence towards men $(\mathrm{BM})$ for men $(\mathrm{t}(421)=-5,18 \mathrm{p}<0,05)$. In other words, male participants had more hostile attitudes towards women in ASI and female participants had more hostile attitudes towards men in AMI. When the correlations among the sub-factors of AMI and ASI are considered, the correlations between HM and BS (0.47), BM and HS (0.47), and BM and BS (0.40) are statistically important. These findings suggest that the benevolent attitudes towards men are in a positive relationship with both benevolent and hostile sexism against women.

Conclusions: The obtained data suggest that the students who continue their education in University of Cumhuriyet have traditional attitudes on social sexism.

Keywords: Sexism, ambivalence sexism, hostile sexism, benevolent sexism

\section{ÖZET}

Amaç: Çelişik Duygulu Cinsiyetçilik kuramı temelinde geliştirilen Çelişik Duygulu Cinsiyetçilik Ölçeği (ASI) ile Erkeğe İliş̧in Çelişik Duygular Ölçeği’ni (AMI) test etmektir.

Yöntem: Örneklem (252 kadın ve 169 erkek) 422 üniversite öğrencisinden oluşmaktadır. Araştırmada öğrencilerin sosyo-demografik özelliklerini belirlemek amacıyla bir anket soru formu ve toplumsal cinsiyetçilik eğilimlerini ölçmek amacıyla AMI ve ASI kullanılmıştır. Cumhuriyet Üniversitesi Rektörlüğünden izin alındıktan sonra uygulama ilgili fakülte ve yüksekokullarda 
görevli akademik personelin yardımı ile $01.02 .2012 \quad 30.04 .2012$ tarihleri arasında gerçekleştirilmiştir.

Bulgular: ASI ve AMI'den elde edilen puanların genel ortalaması (ASI x=4,12; AMI x=4,22 ile) katılımcıların birbirlerine karşı çelişik duygularının ortalamanın üzerinde olduğunu, ASI'de erkek öğrencilerin $(x=4,23)$ kız öğrencilere $(x=4,05)$ karşı, AMI'de de kız öğrencilerin $(x=4,38)$ erkek öğrencilere $(x=3,99)$ karşı daha çelişik duygular içinde olduğunu göstermektedir. Varyans analizinden elde edilen veriler katılımcılar arasında cinsiyete göre anlamlı bir farkl11ık olduğunu, bu farkın ASI'de erkek öğrencilerde düşmanca cinsiyetçilikten (HS) (t(421)=-7,99 p<0,05), kız öğrencilerde korumacı cinsiyetçilikten (BS) $(\mathrm{t}(421)=4,28 \mathrm{p}<0,05)$, AMI'de ise erkek öğrencilerde korumac1 tutumlardan $(\mathrm{BM})(\mathrm{t}(421)=-5,18 \mathrm{p}<0,05)$ ve kız öğrencilerde de düşmanca tutumlardan $(\mathrm{HM})(\mathrm{t}(421)=-15,33 \mathrm{p}<0,05)$ kaynaklandığını göstermektedir. Bir başka deyişle erkek öğrenciler ASI'de kız öğrencilere karşı, kız öğrenciler de AMI'de erkek öğrencilere karş1 daha düşmanca tutumlara sahiptirler. AMI ve ASI alt faktör korelasyonlarına bakıldığında HM ile BS $(0,47)$; BM ile HS $(0,47)$ ve BM ile BS $(0,40)$ arasında istatistiksel açıdan anlamlı bir ilişki olduğu görülmektedir. Bu sonuçlar erkek öğrencilere karşı korumacı tutumlar ile kız öğrencilere karşı hem korumacı hem de düşmanca cinsiyetçilik arasında anlamlı bir iliş̧i olduğunu göstermektedir.

Sonuç: Elde edilen veriler Cumhuriyet Üniversitesinde öğrenimine devam eden öğrencilerin toplumsal cinsiyetçilik konusunda geleneksel tutumlara sahip olduklarını göstermektedir.

Anahtar sözcükler: Cinsiyetçilik, çelişik duygulu cinsiyetçilik, düşmanca cinsiyetçilik, korumacı cinsiyetçilik.

\section{INTRODUCTION}

Glick and Fiske ${ }^{1}$, who emphasize the importance of how sexes in the heterosexual dimension perceive each other and how they feel in understanding social sexist attitudes, mention the differences, which differentiate this relation from the other group relations highlighting the dissimilarity of the relations between men and women as a social group. According to them, no other group can stand such an unequal relationship arising from status differences for a long time, in spite of their physical and psychological intimacy. The reason for this is that women as wives, mothers, and emotional partners have a dyadic power that binds men to them (which makes men dependent on women and empowers women against men in romantic sexual relationship between people), although men have more control and (structural) power on social, political and economic institutions both historically and culturally, compared to women. Within the context of Ambivalent Sexism, which they developed on the basis of these ideas, Glick and Fiske ${ }^{2}$ claim that the structural power of men and the dyadic power of women together can cause ambivalence consisting of hostile and benevolent attitudes of the sexes towards each other. While they try to evaluate ambivalence of men toward women with the Ambivalent Sexism Inventory ${ }^{1}$ that they firstly developed to prove their claims; they also try to show the possibility of an observation of a similar ambivalence in women's attitudes towards men by using Ambivalence toward Men Scale ${ }^{2}$ they developed secondly based on the same theoretical background.

According to the concept of Ambivalent Sexism $^{2}$, social sexism consists of hostile sexism and benevolent sexism. Hostile sexism dimension (HS) of the Ambivalent Sexism Inventory (ASI) consists of men's power, traditional sexual roles and men's attributing humiliating characteristics to women, seeing them as sexual objects, and justifying their abuse; benevolent sexism dimension (BS) includes romantic and sexual relationship with women (the dyadic power of women) and the dependency of men on women for this reason. Hostile sexism dimension (HM) of the Ambivalence Toward Men Inventory (AMI) includes the idea that men do not have abilities in the roles related to women (especially in housework), and the resentment of 
women against men's power and their misuse of this power; on the other hand, benevolent sexism dimension (BM) approaches traditional social roles of the sexes and power relations in a positive light and includes justifying them. The common arguments of hostile and benevolent sexism are the acceptance of traditional sexual roles and the attempts to justify and sustain paternalistic social structure. Theoretically, these two forms of sexism are related to three subcomponents, each of which has hostile and benevolent aspects both in the Ambivalence toward Men Inventory and the Ambivalent Sexism Inventory. These are as follows: 1- Power, 2Gender differentiation, and 3- Sexuality. 1,2

1- Power. As a result of paternalism, gender differences in power are rationalized through paternalistic ideology. The hostile aspect of this ideology in ASI is dominative paternalism, which is based on the idea that women must be controlled by men; and in AMI it is resentment of paternalism, which is based on the claim that women who are loaded with a negative identity by men and undergo biased attitudes can develop negative attitudes against men by resenting these attitudes. The idea that men must protect women and sustain their requirements, for men are more powerful, more influential and physically stronger than women, forms the protective paternalism part of paternalistic ideology in ASI. Protectionism is powerful when men are dependent on women- in a dyadic senseand appropriate them (as wives, mothers, and daughters of men). Matriarchy, which is the first component of BM in AMI, is based on the claim that women assume that men are weak, and women create attitudes and behaviors against men to justify their own benevolent and repressive characteristics.

2- Gender differentiation. They are stereotypes shared about the characteristics of men and women.
These stereotypes help to strengthen the man and maintain his power when men are characterized by high-status roles, and women are characterized by low and intrafamilial status roles. Competitive gender differentiation in ASI and compensatory gender differentiation in AMI form the hostile aspect of this approach. The first is based on the conception that men will gain strong self-confidence by believing that they are better than women through their negative stereotypes towards women, and the second is based on the conception that women will try to differentiate themselves from men through their positive characteristics despite their low status. On the other hand, due to the dependence of men on women, the traditional stereotypes of men about women also include many (protective) attitudes evaluated using a very positive approach. This is complementary gender differentiation including the characteristics of women that are consistent with their traditional gender roles (as mothers, wives), and the characteristics of men, regarding which they are dependent on women in order to perform their roles (such as romantic and sexual relationship and sexual productivity). In these roles, women are evaluated with characteristics according to traditional stereotypes of men (for example, women are naive) and with characteristics that are complementary to traditional stereotypes about them (for example, men are competitive in the business world). The protectionist attitudes of women towards men can be caused by the admiration for high status of a man. Complementary gender differentiation in AMI is based on the idea that women can develop respect for the power and skills of men by recognizing that they are less ambitious, intelligent and talented than men, and on the other hand, they can complete men with their other features (being adept at housework, being devoted, etc.).

3- Sexuality: Heterosexuality, in which close relationships (such as sexual desires and fears) between men and 
women are discussed, is the final component of ambivalent sexism approach with its hostile and protectionist aspects. While heterosexual hostility in ASI reflects the men's tendency to see women only as sexual objects as a result of the fear that women use their sexual attractiveness to gain power on men, for the sexual attraction of men is the main source of women's dyadic power; in AMI it is claimed that, as a result of the fact that women resist the sexual aggression of the men and the paternalistic characteristic of the close relationship between the genders, women can develop hostile attitudes towards men. While in ASI heterosexual intimacy, which is the protectionist aspect of heterosexuality, includes the romanticization of women as sexual objects, the idea that a man can be a real man only if he has an emotional partner, in other words, the romantic relations with a woman; the idea that women need a romantic partner, a man for their personal integrity, and, therefore, men should care and love women by showing great respect for them forms the heterosexual intimacy in AMI.

In short, According to Glick and Fiske ${ }^{1}$, there are many reasons for men and women as a group to develop ambivalent feelings towards each other. On one hand, while women resent the fact that men have more control and (structural) power on social, political and economic institutions than women and the social gender approach based on the superiority of men, and try to resist them, on the other hand, they also keep positive feelings including admiration and affection for each other, for they are in close heterosexual relationships. It is claimed that the feelings, the negative and positive features of which are conflicting with each other, develop among the women who have traditional attitudes towards men. Because women learn how to behave towards men in such power relations, and they perceive acceptance of these conditions as the most effective way to get on well with men.

The aim of this study is to test ambivalent sexism inventory and ambivalence towards men inventory, which were developed on the basis of the ambivalent sexism approach. The importance of the study is that, unlike other attitude inventories, the abovementioned inventories consider the traditional sexism as the result of the alleged ambivalent attitudes (in hostile and protectionist aspect) of the genders that they develop towards each other, and it provides the opportunity to assess the causes and persistence of sexism from two different dimensions.

\section{METHODOLOGY}

The target population of this study consist of the students (17.976) of 13 faculties and 3 vocational schools located at Cumhuriyet University Central Campus, who continue regular education. The number of samples was calculated as 17 using the proportional stratified sampling, however, considering the validity and reliability of the study, the number of samples was recognized as 600; however, the attendance of 422 students from 10 faculties and 3 vocational schools to the study was able to be achieved.

Survey questionnaire and social sexism scales were used to obtain data. After obtaining the permission from the Rectorate of Cumhuriyet University, the application was carried out with the help of academic staff at relevant faculties and vocational schools between 01.02.2012 and 30.04.2012.

The questionnaire form consists of 10 questions prepared to determine the socio-demographic characteristics of students.

\section{Scales:}

1-Ambivalent sexism inventory: ASI developed by Glick and Fiske ${ }^{2}$ consists of 22 articles. 11 of these articles measure benevolent sexism (BS), and the remaining articles measure hostile sexism (HS), and there are no articles to 
be encoded reversely. Participants stated to what extent they agreed with each of the 6 grades on a Likert-type scale. In this scale 1 means "I totally disagree", and 6 means "I completely agree." The high scores obtained from the scale show that benevolent and hostile sexism are high. As a result of the confirmatory factor analysis, Glick and Fiske ${ }^{2}$ stated that the factor structure, which represented the Ambivalent Sexism Inventory (ASI) in the best way, was two factors consisting of hostile sexism and benevolent sexism, and three subfactors (protective paternalism, complementary gender differentiation, and heterosexual intimacy) developed under benevolent sexism. Hostile sexism, which is present as a single factor, includes dominative paternalism, competitive gender differentiation, and heterosexual hostility. Cronbach $\alpha$ value calculated for the scale in this study was .75 ( $\alpha$ value for HS is 0.82 and for BS $0.65)$, and that none of the variables had a negative relationship with total correlation shows that scale's internal consistency was $\operatorname{good}^{3}$. This scale developed by Glick and Fiske $^{2}$ was translated into Turkish by Sakalli Ugurlu for the study of Glick et al. ${ }^{4}$

2-Ambivalent towards men inventory. AMI developed by Glick and Fiske had consisted of 20 articles at the beginning. However, later an article (the possibility that men will lose themselves in emergency situations is lower than that of women) belonging to the benevolence towards men sub-factor was removed from the scale, for it did not give good results; so the number of articles of the scale was reduced to 19.10 articles of the scale measure hostility attitudes towards men (HM) and 9 articles measure benevolence towards men (BTM). Participants stated to what extent they agreed with each of the articles on a Likert-type scale with 6 grades as in ASI. High scores obtained from the scale indicate that hostile and protectionist attitudes towards males are high. In the internal consistency reliability analysis, Cronbach $\alpha$ coefficient calculated for the scale was found as 0.78 (N-422, article number19), Cronbach $\alpha$ coefficient for HAM was found as 0.73 , and Cronbach $\alpha$ coefficient calculated for BTM was found as 0.74 . That none of the variables had a negative relationship with total correlation shows that scale's internal consistency was good $^{3}$, for 0.70 coefficient was considered sufficient for reliability ${ }^{6}$. On the other hand $\alpha$ Cronbach's coefficients found in this study showed a high consistency with the studies of Glick et al. ${ }^{4}$ and Sakallı Ugurlu? .

The data obtained from the survey were subjected to average, variance and correlation analysis. The analysis was carried out at $95 \%$ confidence level, and SPSS 16.0 software package was used for the analysis.

\section{RESULTS}

Table 1. General findings

\begin{tabular}{lll}
\hline & Number & $\%$ \\
\hline Gender & & \\
Female & & \\
Male & 252 & 59,7 \\
Department & 169 & 40,0 \\
Medicine & 31 & 7,3 \\
Dentistry & 10 & 2,4 \\
Literature & 78 & 18,5 \\
Science & 38 & 9,0 \\
Economy & 57 & 13,5 \\
Communication & 5 & 1,2 \\
Engineering & 31 & 7,3 \\
Health Sciences & 60 & 14,2 \\
Fine Arts & 10 & 2,4 \\
Theology & 5 & 1,2 \\
Pesvs & 10 & 2,4 \\
Cvhs & 43 & 10,2 \\
Svhs & 43 & 10,2 \\
Cvi & 1 & 0,2 \\
\hline Total & 421 & 99.8 \\
\hline
\end{tabular}

Pesvs: Physical Education and Sports Vocational School; Cvs: Cumhuriyet Vocational High School; Svs: Sivas Vocational High School 
General Average of the Expressions in Ambivalent Sexism Inventory and Ambivalence Towards Men Inventory and Gender Difference

When the overall average of the scores obtained from ASI and AMI were considered, it was found out that the ambivalence of the participants against each other (ASI $x=4,12$; AMI $x=4,22$ ) was above the average; and Men ( $\mathrm{x}=$ $4,23)$ had more ambivalence compared to women $(x=4,05)$ in ASI, and women $(\mathrm{x}=4,38)$ had more ambivalence compared to men $(x=3,99)$ in AMI. HS factor average of men $(x .=4,49)$ was higher compared to women and BS factor average of women $(x=4,30)$ was higher compared to men in ASI; HM factor average of women $(x=5,14)$ was higher compared to men (Av. $=3,58)$, and $\mathrm{BM}$ factor average of men $(\mathrm{x}=4,45)$ was higher compared to women $(x=4,00)$ in $\mathrm{AMI}^{3}$. The data obtained from the variance analysis suggested that there were significant differences among the participants by gender, which were HS for men $(\mathrm{t}(421)=-7,99 \mathrm{p}<0,05)$, BS for women $(\mathrm{t}(421)=4,28 \mathrm{p}<0,05)$ in ASI; and $\mathrm{HM}$ for women $(\mathrm{t}(421)=-15,33$ $\mathrm{p}<0,05)$, BM for men $(\mathrm{t}(421)=-5,18$ $\mathrm{p}<0,05)$. In other words, male participants had more hostile attitudes towards women in ASI and female participants had more hostile attitudes towards men in AMI.

Table 2. Mean and standard deviation values of ASI and AMI, and correlation coefficients between them.

\begin{tabular}{|c|c|c|c|c|c|c|c|c|}
\hline \multicolumn{3}{|c|}{$\begin{array}{cc}\text { Av. } & S \\
\text { TOTAL DATA }\end{array}$} & AMI & ASI & HM & $\mathrm{BM}$ & \multirow[t]{2}{*}{ HS } & \multirow[t]{2}{*}{$\mathrm{BS}$} \\
\hline AMI & 4,23 & ,71 & - & & & & & \\
\hline ASI & 4,13 & ,62 & $.54^{* *}$ & & & & & \\
\hline HM & 4,27 & ,93 & $.79^{* *}$ & $.25^{* *}$ & - & & & \\
\hline BM & 4,19 & ,93 & $.73^{* *}$ & $.58^{* * *}$ & $.16^{* *}$ & - & & \\
\hline HS & 4,09 & ,90 & $.26^{* *}$ & $.80^{* *}$ & -.04 & $.47^{* *}$ & & \\
\hline $\mathrm{BS}$ & 4,17 &, 75 & $.57^{* *}$ & $.69^{* *}$ & $.47^{* *}$ & $.40^{* *}$ & $.12^{*}$ & - \\
\hline \multicolumn{9}{|c|}{ FEMALE ONLY } \\
\hline AMI & 4,38 & ,72 & - & & & & & \\
\hline ASI & 4,06 & ,63 & $.65^{* *}$ & - & & & & \\
\hline HM & 4,73 & ,73 & $.81^{* *}$ & $.54^{* *}$ & - & & & \\
\hline BM & 4,01 & ,97 & $.87^{* *}$ & $.57^{* *}$ & $.42^{* *}$ & - & & \\
\hline DHS & 3,82 & ,84 & $.45^{* *}$ & $.83^{* *}$ & $.33^{* *}$ & $.42^{* *}$ & - & - \\
\hline $\mathrm{BS}$ & 4,30 & ,73 & $.62^{* *}$ & $.77^{* *}$ & $.55^{* *}$ & $.50^{* *}$ & $.290^{* *}$ & - \\
\hline \multicolumn{9}{|c|}{ MALE ONLY } \\
\hline AMI & 4,00 & 63 & - & & & & & \\
\hline ASI & 4,24 & ,59 & $.51^{* *}$ & - & & & & \\
\hline HM & 3,58 & ,76 & $.83^{* *}$ & $.25^{* *}$ & - & & & \\
\hline BM & 4,45 & ,78 & $.79^{* *}$ & $.59^{* *}$ & $.33^{* *}$ & - & & \\
\hline HS & 4,49 & ,84 & $.32^{* * *}$ & $.78^{* *}$ & .086 & $.46^{* *}$ & - & - \\
\hline BS & 3,98 &, 74 & $.44^{* *}$ & $.70^{* *}$ & $.31^{* *}$ & $42^{* *}$ & .10 & - \\
\hline
\end{tabular}

AMI $=$ Ambivalence toward Men Inventory, ASI $=$ Ambivalent Sexism, HM= Hostility attitudes towards men, $\mathrm{BM}=$ Benevolence towards men, $\mathrm{HS}=$ Hostile sexism, $\mathrm{BS}=$ Benevolent sexism

The correlations between AMI and its sister ASI, which measure similar subjects, and the correlations among sub-factors of each scale were calculated separately for total data, for women and men, and were given in Table 2. 
As can be seen in Table 2, that the presence of a positive relationship between AMI and ASI ( $r=0,54, N=421$, $\mathrm{p}<.01)$ in terms of total data suggests that ASI is successful in measuring ambivalent attitudes of men towards women in traditional aspect, and ASI is successful in measuring ambivalent attitudes of women towards men in traditional aspect.

When the correlations among the subfactors of AMI and ASI are considered, the correlations between $\mathrm{HM}$ and BS (0.47), BM and HS (0.47), and BM and BS (0.40) are statistically important. These findings suggest that the benevolent attitudes towards men are in a positive relationship with both benevolent and hostile sexism against women, and it supports the traditional social roles of genders and power relations. No statistically important relationship was able to be established between HM and HS in terms of total data. On the other hand, when the reason for the absence of a relationship between these two sub-factors is evaluated taking the gender differentiation into consideration, it will be seen that no statistically important relationship can be established between HM and HS for male participants, not for female participants.

When the sub-scales are examined separately for female and male participants, it will be seen that the correlations between AMI and ASI $(0,65)$, and sub-factors of both scales are statistically important for female participants. The correlations between $\mathrm{BM}$ and BS $(0,50)$, and $\mathrm{HM}$ and $\mathrm{BS}$ $(0,55)$ are higher compared to men.

For male participants, a statistically important relationship is observed between HM and BS $(0,31)$ and between BM and HS $(0,46)$, except between HM and HS $(0,08)$. In this study, the BM and HS correlation scores of the male participants are higher than correlation scores between BM and BS compared to female participants.

\section{DISCUSSION}

$60 \%$ of those participating in the study were males, and $40 \%$ were females.

When the overall average of scores obtained from Ambivalent Sexism Inventory and Ambivalence Towards Men Inventory were considered, it was found out that the ambivalence of students towards each other was above the average, male students had more hostile attitudes compared to female students in ASI, and female students had more hostile attitudes compared to male students in AMI.

When the correlations between AMI and its sister ASI, which measure similar subjects, and the correlations among sub-factors of each scale are considered separately for total data, for women and for men (Table 2), it can bee seen that there is a statistically important relationship between ASI and AMI, and both scales measure attitudes, which are based on similar grounds.

When we consider the correlations among sub-factors of both scales, we observe that the sub-factor correlations (between HM and BS, BM and HS, and BM and BS, except HM and HS), are statistically important in terms of total data. Coinciding with the results of the studies ${ }^{1,7}$ conducted before, these results suggest that BM supports traditional social roles of genders and power relations and is in positive relations with both BS and HS. Glick and Fiske ${ }^{1}$ also stated in their study that there was a positive relationship between BS and $\mathrm{BM}$, and $\mathrm{HS}$ and $\mathrm{BM}$; that, on one hand, the relationship between BS and BM resulted from the fact that genders needed each other and, in this context, they were perceived as two parts of a whole; on the other hand, the relationship between $\mathrm{HS}$ and $\mathrm{BM}$ resulted from the fact that the ones who saw women at a lower position compared to men and had hostile attitudes towards women also had ambivalent attitudes towards men at the same time. On the other hand, no 
significant relationship between HM and HS was observed. What was emphasized in the study conducted by Glick et al. ${ }^{1}$, is that no strong relationship can be observed between HM and HS. The reason for this is that these two subfactors measure the attitudes in the same direction, in other words, hostile attitudes with expressions, which base these attitudes on gender differentiation. Namely, HS tries to measure the hostile attitudes of men towards women with expressions justifying men in traditional dimensions, and HM tries to measure the hostile attitudes of women towards men together with that the acceptance of such traditional arrangements is a resistance to the power of men rather than obviously justifying traditional roles of the gender. When it was evaluated considering the gender difference, that a meaningful relationship was found between HM and HS only in female participants suggests that women who were showing more resistance to the power of men and had more hostile attitudes towards men in traditional sexist order, which tried to justify the sovereignty of men were the women who were exposed to hostile sexism by men.

When the relations between subscales are examined separately for women and men, the view becomes clearer. Namely; for female participants, the correlations between AMI and ASI and sub-factors of both scales are statistically significant. That a meaningful relationship was found between HM and HS suggested that there was a meaningful relation between the fact that women had hostile attitudes towards men and the fact that they were exposed to hostile attitudes by men. In the study of Glick et al. ${ }^{1}$, it was stated that, as hostile sexism scores increased within the context of ASI, the hostile attitudes of women towards men increased within the context of AMI, in other words, hostile sexism towards women and that women resented men and saw them as hostile were associated with each other. Again, the establishment of a relationship between $\mathrm{HM}$ and $\mathrm{BS}$ for women suggested that women who had hostile attitudes towards men approved the benevolent attitudes towards women; additionally, the relationship between $\mathrm{BM}$ and BS suggested that women who were in favor of benevolent attitudes towards women had the same benevolent attitudes towards men at the same time. As suggested in the previous studies $^{1,7}$, the high correlations between $\mathrm{BM}$ and BS, and HM and BS suggested that women tended to perceive the hostile attitudes towards men and benevolent sexism towards women as similar, in other words, they were resisting the sovereignty of men in a traditional sexist order on one hand, on the other hand, they were positively approaching the protectionist and caring attitudes of men towards women. These data also confirm the claims of Glick ad Fisk $^{1}$ that the emotions contrasting with their positive and negative characteristics develop among women who have traditional attitudes towards men. Because women learn in such power relations how to behave towards men, and they perceive that the acceptance of these conditions is the most effective way to get on well with men.

For female participants, meaningful relations were observed between subfactors, except HM and HS. The establishment of a meaningful relationship between HM and BS for men suggests that the hostile attitudes of women towards men are effective not on the development of hostile sexist attitudes towards women but on the development of benevolent attitudes. In this regard, when the fact that BS is a sexist approach supporting the sovereignty of men and generally harming women is taken into consideration, the positive relationship between HM and BS for men suggests that men use their ostensible positive attitudes such as protecting, glorifying and loving women, in fact, in order to maintain traditional sexist stereotypes and sovereignty of men. It was also stated by the researchers ${ }^{1,5,7}$ that although it created positive emotions in 
the perceiving persons, benevolent sexism was a type of sexism, which supported traditional stereotypes and sovereignty of men and generally harmed women. Again, that a meaningful relationship between BM and HS was found for men and that the scores of male participants in BM and HS were higher than those of female participants suggested that the men who had hostile attitudes towards women were, at the same time, those who wanted to be protected and cared by women. When the fact is taken into consideration that $\mathrm{BM}$, which consists of matriarchy, complementary gender differentiation and heterosexual intimacy, includes the attitudes such as showing maternal behaviours towards men, protecting them at home, thinking that men and women fulfill complementary social roles and not being able to think of a life without men, it would be concluded that the men approving these attitudes are those sexist men who want the current roles of genders to continue and try to base these attitudes on justification ${ }^{7}$. When the relationships between subcomponents of AMI were evaluated, that a statistically significant relationship between complementary gender differentiation sub-component and only matriarchy sub-component $(\mathrm{r}=0,18 \mathrm{p}>$ $.01)$ was detected among male participants suggested that women were associated more with domestic responsibilities, and the maternal attitudes of women were more determinant on the development of benevolent attitudes of men towards women compared to other attitudes ${ }^{8}$. In other words, it can be said that the efforts of women to differentiate themselves from men and see themselves superior to men are approved by men as well when housework (matriarchal attitudes) is concerned.

\section{CONCLUSIONS}

This study is a study in which ambivalent sexism inventory and ambivalent towards men inventory, which brought a new perspective on the attitudes of men and women towards each other in sexism and were developed on the basis of the ambivalent sexism theory, were tested on a particular sample group. In the study, the correlation between sub-factors of ASI and AMI was examined, and it was tried to determine which attitudes were effective on the development of conflicting emotions of genders towards each other in hostile and benevolent dimensions. It can be concluded that women (students) express more hostile behavior and resistence to supremacy and power of men especially when they more realize the existence of hostile sexsism, on the other hand they lean towards being loved, protected, praised by males. The males (students) who have benevolent attitudes express more positive behaviors towards women especially when their indoor responsibilities and the maternal attitudes are being talked about. These data reflect that Cumhuriyet University students have conservative attitudes about social sexism.

\section{REFERENCES}

1- Glick P. Fiske ST. The ambivalence toward men inventory: Differentiating hostile and benevolent beliefs about men. Psychology of Women Quarterly, 1999; 23: 519-36.

2- Glick P. Fiske ST. Hostile and benevolent sexism: measuring ambivalent sexist attitudes toward women. Psychology of Women Quarterly, 1997; 21. 119-36.

3- Ayan S. Sexism: Ambivalent Sexism. CMJ 2014; 36: 147-56.

4- Glick P. Fiske ST. Mladinic A. Saiz Jl. Abrams D. MASIer B. et al., Beyond prejudice as simple antipathy: Hostile and benevolent sexism across cultures. Journal of Personality and Social Psychology. 2000; 75: 763-75.

5- Sakallı Uğurlu N. Çelişik duygulu cinsiyetçilik ölçeği: Geçerlik ve güvenirlik çalışması. [Ambivalent Sexism Scale: Validity and 
Reliability Study] Türk Psikoloji Dergisi. [Turkish J Psychol] 2002; 17(Suppl.49): 47-58.

6- McIntire SA. Miller LA. Foundation of psychological testing. Boston: McGraw Hill. 2000.

7- Sakallı Uğurlu N. Erkeklere ilişskin çelişik duygular ölçeğinin Türkçe'ye uyarlanması. [Turkish Adaption of Ambivalent Towards Men Inventory] Türk Psikoloji Yayınları, [Turkish Psychology Publications] 2008; 11; 21:1-11.

8- Ayan S. Sexism: Ambivalence toward men. J Human Sci. 2016; 13: 1 